\title{
Assessing the Parameters for Optimum Biotransformation of Carbonaceous Matter by Phanerochaete chrysosporium
}

\author{
Grace Ofori-Sarpong $^{1,2}$, Kwadwo Osseo-Asare ${ }^{2,3}$, Richard Osei ${ }^{1, ~ *, ~ R i c h a r d ~ K w a s i ~ A m a n k w a h ~}{ }^{1}$ \\ ${ }^{1}$ Department of Minerals Engineering, University of Mines and Technology, Tarkwa, Ghana \\ ${ }^{2}$ Department of Energy and Mineral Engineering, Penn State University, Pennsylvania, USA \\ ${ }^{3}$ Department of Materials Science and Engineering, Penn State University, Pennsylvania, USA
}

Email address:

gofori-sarpong@umat.edu.gh (G. Ofori-Sarpong), ako1@psu.edu (K. Osseo-Asare), richardosei328@yahoo.com (R. Osei), rkamankwah@umat.edu.gh (R. K. Amankwah)

${ }^{*}$ Corresponding author

\section{To cite this article:}

Grace Ofori-Sarpong, Kwadwo Osseo-Asare, Richard Osei, Richard Kwasi Amankwah. Assessing the Parameters for Optimum Biotransformation of Carbonaceous Matter by Phanerochaete chrysosporium. Advances in Bioscience and Bioengineering. Vol. 5, No. 6, 2017, pp. 107-114. doi: 10.11648/j.abb.20170506.13

Received: October 12, 2017; Accepted: November 1, 2017; Published: December 18, 2017

\begin{abstract}
Refractory carbonaceous gold ores pose challenges during cyanidation of gold due to the presence of carbonaceous matter (CM) which preg-robs dissolved gold, and this results in a decreased recovery. In an on-going study, the fungus, Phanerochaete chrysosporium has been used to deactivate $\mathrm{CM}$ and decrease its ability to preg-rob aurocyanide. $P$. chrysosporium has been reported to biotransform CM by surface oxidation, which leads to disruption of the continuous graphitic structure necessary for adsorption, and alteration of the pores suitable for aurocyanide adsorption. The present study focused on using anthracite coal as surrogate for CM, and establishing fungal-treatment parameters that bring about maximum decrease in preg-robbing by the anthracite-grade CM. The results indicate that $P$. chrysosporium can survive in several growth media, and possesses the ability to deactivate anthracite in a wide range of time, pulp density, temperature, $\mathrm{pH}$, and level of agitation. A processing time of 5-7 days at $\mathrm{pH} 4$ and $37^{\circ} \mathrm{C}$ gave the best conditions. The best pulp densities for stationary and shake culturing respectively were $60 \%$ and $25 \%$.
\end{abstract}

Keywords: Fungi, Biotransformation, Incubation Parameters, Carbonaceous Matter, Aurocyanide Adsorption, Preg-Robbing

\section{Introduction}

Refractory carbonaceous gold ores are those that contain carbonaceous matter $(\mathrm{CM})$, which adsorbs dissolved gold during cyanidation, resulting in reduced gold extraction. This effect, termed "preg-robbing", presents a serious and challenging problem in the extraction of gold from refractory carbonaceous gold ores, and several techniques have been investigated to deactivate $\mathrm{CM}$ and prevent this metal loss. Among these techniques are roasting, chemical treatment using organic reagents and microbial pretreatment $[1,2,3,4,5$, $6,7,8,9,10,11,12]$.

\subsection{Microbial Pretreatment of Carbonaceous Matter}

Microbial pretreatment processes are gaining importance as potential alternatives on grounds of cost and environmental issues, due to the relatively lower operating temperatures and the fact that microorganisms can rejuvenate themselves to recycle reagents needed for the reaction. A number of bacteria and fungi have been tested for the deactivation of different grades of CM in gold ores, and there are reports of increase in overall gold extraction. Among the microorganisms used are the bacteria Streptomyces setonii, Pseudomonas spp., Achromobacter spp., Arthrobacter spp. and Rhodococcus spp., and the fungi Trametes versicolor, Phanerochaete chrysosporium, Aspergillus bruneio-uniseriatus and Penicillium citrinum [6, 9, 12-14].

In an investigation on biodegradation of lignite, bituminous 
and anthracite coals, used as surrogates for CM, Amankwah and Yen [4] observed a more extensive biodegradation in lignite and bituminous coal than in anthracite, when they used $S$. setonii. In a solution of $5 \mathrm{mg} / \mathrm{L} \mathrm{Au}$, biotreatment reduced the gold adsorption capacity of bituminous, lignite and anthracite coals respectively from an average of about $19 \%$ to $0.3 \%, 22 \%$ to $9 \%$ and $45 \%$ to $20 \%$. Yen et al [14] and Afidenyo [15] also reported on the decrease in the preg-robbing effect of bituminous coal from $40.3 \%$ to $8.3 \%$ and anthracite from 99.5 to 27.7 when they used the white-rot fungus, Trametes versicolor.

There has been increased interest in deactivating anthracite-grade $\mathrm{CM}$ as it comprises more than $50 \%$ of the components of CM in refractory gold ores [16-22]. In addition, anthracite-grade CM has a far higher capacity to adsorb gold than bituminous and lignite coals due to the maturity and thus well-developed graphitic structure of anthracite $[4,11,12,15$, 23- 26]. Consequently, identifying microorganism that can deactivate anthracite and reduce its gold adsorption significantly will be of immense benefit in the treatment of carbonaceous gold ores.

Ofori-Sarpong et al. [11] studied the interaction of different ranks of coal with aurocyanide solution, and observed that, of all the coals, anthracite interacted the strongest with dissolved gold, about 4 folds as much as lignite and bituminous coal. Nevertheless, after biotreatment of the coals with the fungus, Phanerochaete chrysosporium, adsorption by anthracite decreased the most. The authors subsequently used characterisation techniques to elucidate the mechanism of the biotransformation [12].

\subsection{Nature of Biotransformation of Anthracite-Grade CM by $P$. Chrysosporium}

Several studies have been conducted on the nature of biotranformation of carbonaceous materials. In a paper on elucidating the mechanism to better understand the nature of anthracite biotransformation by $P$. chrysosporium, Ofori-Sarpong et al. [12] characterised as-received and treated anthracite using various techniques. The changes in surface characteristics of anthracite were observed by measuring surface area, pore volume and size by BET analysis, and the presence of oxygen groups and aliphatics by Fourier Transform Infrared (FT-IR) and X-ray absorption near edge structure (XANES) spectroscopies. BET and pore size analyses were conducted using a Micromeritics ASAP 2000 Multi-Point BET analyzer and samples were analyzed for pore size by high pressure nitrogen adsorption. FT-IR analysis was carried out in a Bruker IFS 66/S FT-IR Spectrometer whiles XANES analysis was conducted using the National Synchrotron Light Source in Brookhaven National Laboratory, New York. [27, 28]. Confocal WITec XY Raman spectrometer was used for semi-quantitative analysis of the changes in graphitic nature of carbonaceous samples following fungal-treatment by $P$. chrysosporium. After detailed analysis of their results, Ofori-Sarpong et al. [12] concluded that $P$. chrysosporium biotransforms anthracite in three main ways. In one way, there is loss of carbon and surface oxidation by introduction of oxygen groups which disrupts the continuous graphitic structure thus decreasing the active sites necessary for adsorption. This has been confirmed by Liu et al. [29] who studied the influence of $P$. chrysosporiumon on degradation and preg-robbing capacity of activated carbon. The second route is reduction in surface area via plugging of pores possibly by fungal mycelia hence decreasing accessibility of gold to the adsorption sites. Thirdly, there may be enlargement of micropores due to cleavage of graphitic planes by fungal activity, and this will decrease gold adsorption, which occurs preferentially in the micropores of carbon [30].

\subsection{Present Study}

In this present paper, the interaction of $P$. chrysosporium with anthracite and its effect on aurocyanide adsorption is further explored to ascertain the response to changes in parameters such as $\mathrm{pH}$, pulp density, temperature and agitation.

\section{Experimental Investigations}

\subsection{Materials}

Anthracite coal sample with particle size less than $850 \mu \mathrm{m}$ was provided by the Coal Bank of the EMS Energy Institute, whereas fungal spores of $P$. chrysosporium ME446 were obtained from the Ming Tien laboratory of the Department of Biochemistry and Molecular Biology, all in the Pennsylvania State University. The growth media for the fungus, millet and wheat bran (MWB), were obtained from Nature's Pantry, State College, PA and double-distilled (dd) $\mathrm{H}_{2} \mathrm{O}$ was used in preparing the culture. Standard gold solution $(50 \mu \mathrm{g} / \mathrm{ml}$ in $0.1 \%$ sodium hydroxide and $0.05 \%$ sodium cyanide) was supplied by High Purity Standards. Reagent grade potassium phosphate, succinic acid and sodium hydroxide were obtained from the Minerals Engineering Laboratory, University of Mines and Technology, Ghana.

\subsection{Medium Preparation and Fungal Incubation of Anthracite}

Medium preparation, incubation and harvesting of anthracite and gold adsorption (preg-robbing) tests were done as described in detail in Ofori-Sarpong et al. [11]. Anthracite coal was crushed and sieved to all passing $250 \mu \mathrm{m}$ and incubated with $P$. chrysosporium in millet and wheat bran (MWB) medium under different conditions including processing time, pulp density, temperature, $\mathrm{pH}$, degree of sterilisation and agitation. Solid samples and media were sterilized in an autoclave at $121^{\circ} \mathrm{C}$ for $30 \mathrm{~min}$ before inoculation with $1 \mathrm{~mL}$ suspension of spores of $P$. chrysosporium. Agitation was done at $150 \mathrm{rpm}$ on a New Brunswick Series 25 Incubator shaker with temperature control, and $\mathrm{pH}$ was buffered at 4 and 6 with succinic acid and potassium phosphate respectively. 


\subsection{Preg-Robbing of Gold by Fungal-Treated Anthracite}

Triplicate samples of biomodified, control and as-received anthracite were contacted with $250 \mathrm{~mL}$ of $5 \mathrm{mg} / \mathrm{L}$ gold solution and agitated at $150 \mathrm{rpm}$ for 24 hours. At the end of the contact time, the residual solution was filtered and gold in the filtrate, determined using Perkin-Elmer Optima 5300 Inductively Coupled Plasma - Atomic Emission Spectrometer (ICP-AES). The difference between the concentration of gold in solution before and after the adsorption test was computed with respect to the amount of carbon-containing material used for the adsorption.

\subsection{Analysis of Data}

The preg-robbing effect of carbon (PEC), which gives an indication of the extent of fungal-biotransformation on adsorption of gold by carbon [11], was computed using Equation 1. IC and FC respectively are the initial and final concentrations of gold in solution. WC is the mass $(\mathrm{g})$ of carbon material used in the adsorption test, 250 is the volume $(\mathrm{mL})$ of gold solution used, and 197 is the molar mass of gold.

$$
\operatorname{PEC}\left(\text { in } \frac{\mu \mathrm{mol} \text { of gold }}{\mathrm{g} \text { of carbon }}\right)=250 \mathrm{~mL} \times\left(\frac{(\mathrm{IC}-\mathrm{FC})^{\mu \mathrm{g}} / \mathrm{mL}}{197 \mathrm{~g} / \mathrm{mol}}\right)\left(\frac{1}{\mathrm{WCg}}\right)
$$

Comparing with the amount ( $\mu \mathrm{mol} / \mathrm{g}$ ) adsorbed by the as-received anthracite (AAR), percentage reduction in preg-robbing (PRP) was computed as in Equation 2. All the incubation experiments were carried out in triplicates, and the data reported in the figures are mean values of the 3 samples, with the error bars representing the percentage deviations from the means.

$$
\operatorname{PRP}(\%)=\frac{\mathrm{PEC}}{\mathrm{AAR}} \times 100 \%
$$

\section{Results and Discussion}

This paper set out to investigate how the different conditions utilized during fungal treatment of anthracite coal result in decreasing preg-robbing ability of carbonaceous matter $(\mathrm{CM})$. Prior to proceeding with the changing incubation parameters, it was necessary to set the stage on the fact that reduction in preg-robbing ability of $\mathrm{CM}$ is mainly due to surface biotransformation of $\mathrm{CM}$ by Phanerochaete chrysosporium.

The reduction in preg-robbing ability of $\mathrm{CM}$ following fungal treatment is presented in Figure 1. Fungal-treatment was conducted at $60 \%$ solids for 14 days at $37^{\circ} \mathrm{C}$ and $\mathrm{pH} 6.5$. From an initial average adsorption value of $4.5 \mu \mathrm{mol} / \mathrm{g}$ with standard deviation of 0.26 for the as-received sample, gold adsorption reduced to $0.25 \mu \mathrm{mol} / \mathrm{g}$ with standard deviation of 0.05 after 14 days of treatment, representing a reduction of about $95 \%$. The possible contribution of the millet and wheat bran (MWB) medium to the biotransformation action of $\mathrm{CM}$ by $P$. chrysosporium was investigated by means of control experiments, which were set up in a similar manner but without fungal addition.

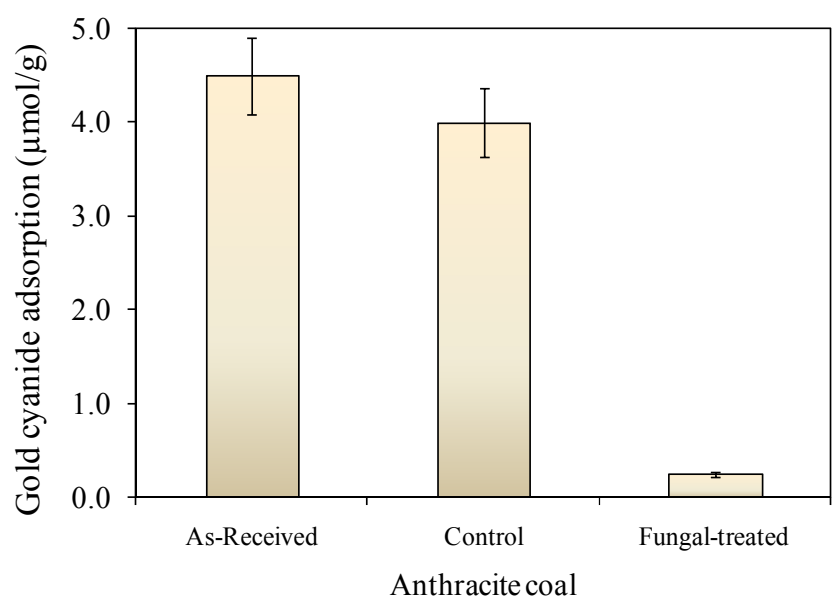

Figure 1. Reduction in preg-robbing by CM after fungal treatment at $60 \%$ solids for 14 days at $37^{\circ} \mathrm{C}$ and $\mathrm{pH}$ 6.5. For adsorption tests, $1 \mathrm{~g}$ of anthracite was contacted with $250 \mathrm{~mL}$ of $5 \mu \mathrm{g} / \mathrm{mL}$ gold solution and agitated at $150 \mathrm{rpm}$ for 24 hours.

As indicated in Figure 1, the control experiment resulted in about $20 \%$ reduction in preg-robbing, ending at a mean value of $4.0 \mu \mathrm{mol} / \mathrm{g}$ with standard deviation of 0.28 . With other parameters remaining constant, more control experiments were set to monitor the influence of temperature, $\mathrm{pH}$ and pulp density on gold adsorption by carbon. For temperature, incubation at $25^{\circ} \mathrm{C}$ was compared with that at $37^{\circ} \mathrm{C}$, whereas $\mathrm{pH}$ of 4 was judged against 6.5 in the case of $\mathrm{pH}$. In both cases, no significant differences in gold adsorption were noticed. Reduction in gold adsorption was about $18 \%$ at $25^{\circ} \mathrm{C}$ as against $20 \%$ at $37^{\circ} \mathrm{C}$. At $\mathrm{pH}$ of 4 , gold adsorption decreased by about $17 \%$ as compared with the $20 \%$ realised at $\mathrm{pH}$ 6.5. Control experiments for the effect of pulp density on gold adsorption yielded similar results.

The slight decline in preg-robbing due to media alone may be attributed to finely suspended particulates that might have blinded some of the pores on the carbon surface $[11,12]$. In the presence of the fungus, there was about 15 -fold decrease in gold adsorption in comparison with the media alone. This indicates clearly the potential of $P$. chrysosporium to lessen the preg-robbing nature of $\mathrm{CM}$ in refractory gold ores.

\subsection{Effect of Pulp Density During Biotransformation on Preg-Robbing by CM}

The effect of pulp density on biotransformation of CM by $P$. chrysosporium is shown in Figure 2. After stationary incubation for 14 days at a pulp density of $25 \%$ solids, reduction in preg-robbing was $88 \%$ from a solution of concentration, $5 \mathrm{mg} / \mathrm{L} \mathrm{Au}$. 


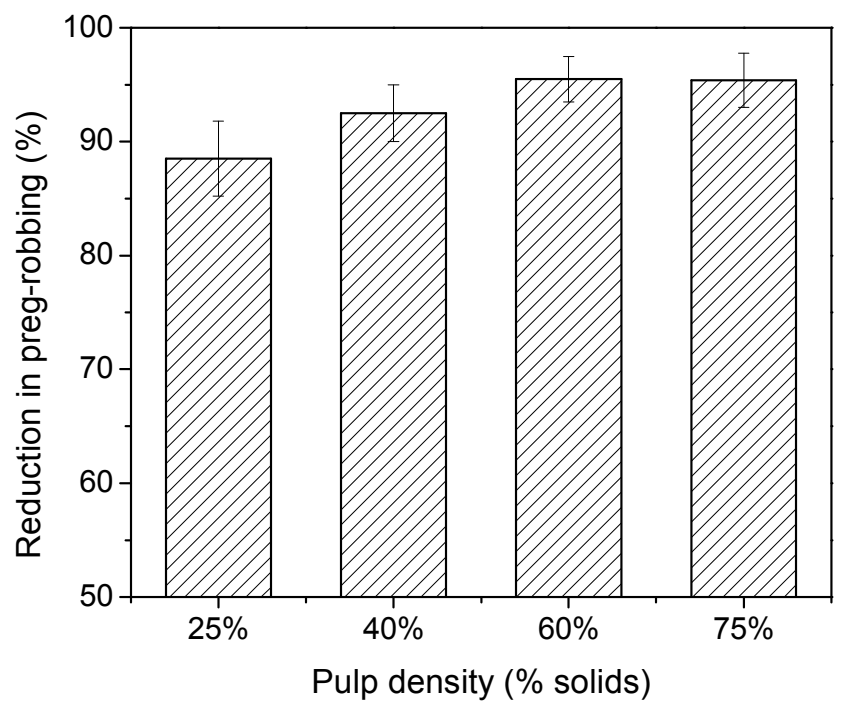

Figure 2. Effect of pulp density during biotransformation on preg-robbing by $C M$. Biotransformation was performed under stationary conditions at $37^{\circ} \mathrm{C}$, pH 6.5 and 14 days.

By using the same initial fungal dosage for stationary incubation with pulp densities of $40 \%, 60 \%$, and $75 \%$, the average percentage reductions in preg-robbing were $92.5 \%$, 95.5\% and 95\% respectively. From Figure 2, incubation pulp densities of $60 \%$ and $75 \%$ led to the highest reduction in preg-robbing by the treated CM. The higher the pulp density, the greater the surface of solids available for fungal contact and growth, hence the observed higher biotransformation in the $60 \%$ and $75 \%$ pulp densities as against the $25 \%$ and $40 \%$ pulp densities, which were almost submerged in water. At solid densities of $60 \%$ and $75 \%$, the media and sample were moistened but did not form a slurry. The discontinuous nature of the moist substrate allowed for the formation of air pockets which provided the oxygen necessary for growth, and this was favourable for the activity of $P$. chrysosporium, which is an aerobe [31].

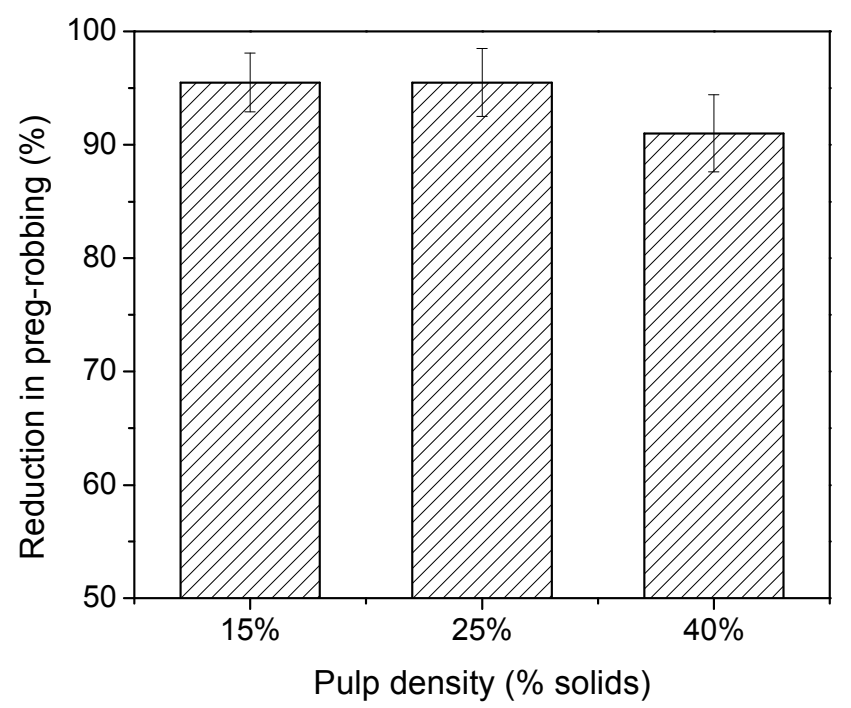

Figure 3. Effect of pulp density during biotransformation on preg-robbing by CM. Biotransformation was conducted in shake culture at $37^{\circ} \mathrm{C}, \mathrm{pH} 6.5$ and 14 days.
For shake cultures, as illustrated in Figure 3, lower pulp densities were utilized, and there was $95 \%$ reduction in average gold adsorption for materials incubated at $15 \%$ and $25 \%$ solids while that of the sample treated at $40 \%$ solids reduced by $91 \%$. At the lower pulp densities, there is improved diffusion of oxygen into the slurry as the sample is agitated, providing the dissolved oxygen required for fungal-growth and activity. In addition, the ratio of oxidants to material being treated is higher with the lower pulp densities. The $25 \%$ pulp density was, however, chosen over $15 \%$ for further studies due to the higher mass of material that can be treated per unit time.

Since the reduction in gold adsorption achieved at pulp densities of $60 \%$ and $75 \%$ after 14 days of fungal treatment were equally good, further investigations were carried out to monitor the effect of fungal-treatment time (Figure 4) on reduction in preg-robbing. After an incubation period of 1 day, the gold adsorption abilities reduced by $78 \%$ for the sample cultured at $60 \%$ solids, and $68 \%$ for that cultured at $75 \%$ solids. After the $5^{\text {th }}$ day, preg-robbing by both samples reduced by more than $90 \%$, and over $95 \%$ by the $7^{\text {th }}$ day. It can be deduced from Figure 4 that a processing time of 5-7 days is suitable for the process.

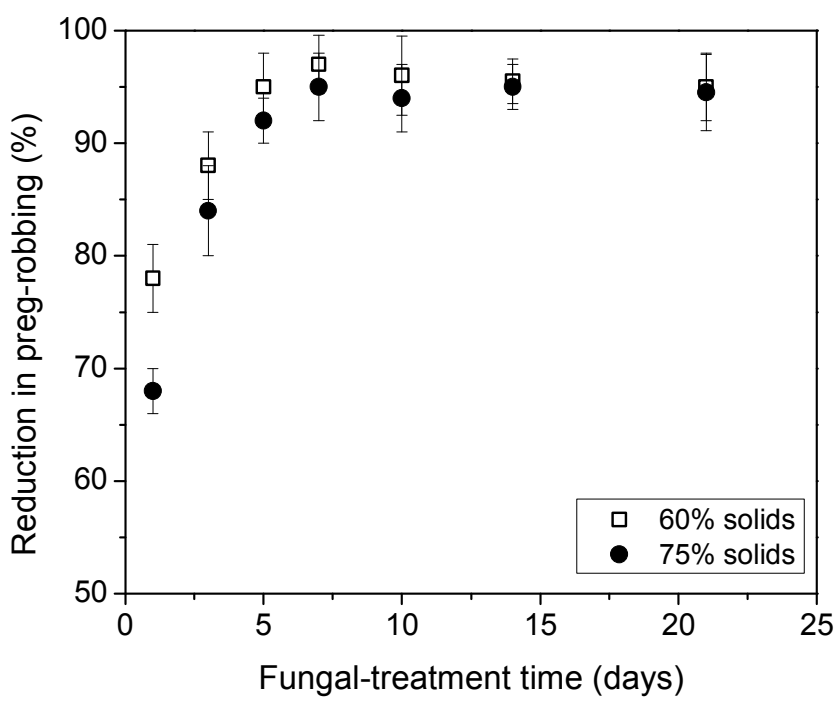

Figure 4. Effect of fungal-treatment time and pulp density on preg-robbing by CM. Biotransformation was conducted at $60 \%$ and $75 \%$ solids under stationary culturing at $37^{\circ} \mathrm{C}$ and $\mathrm{pH} 6.5$.

Due to the reduced presence of water in the $75 \%$ solids material, the fungus grew and formed a matrix that covered the anthracite making post-treatment separation between biomass and sample more difficult. Consequently, a pulp density of $60 \%$ may be preferred on the basis of reduced material losses during post incubation harvesting of treated materials.

The choice between stationary and shake culturing will depend on a balance between volume of material available for treatment and the time and technique available for harvesting treated material. Whereas per unit time, much more material can be treated via stationary than shake culturing, washing of treated material from shake culturing is less cumbersome and can be accomplished at a relatively shorter time with much 
less material losses than in stationary culturing.

\subsection{Effect of Temperature During Biotransformation on Preg-Robbing by CM}

The effect of incubation temperature for stationary culturing at $\mathrm{pH} 6.5$ and $60 \%$ (as a function of time) on preg-robbing by $\mathrm{CM}$ is demonstrated in Figure 5. At a processing temperature of $37^{\circ} \mathrm{C}$, gold adsorption ability decreased by $80 \%$ after the $1^{\text {st }}$ day and further by about $96 \%$ after the $7^{\text {th }}$ day. Beyond this day, the gold adsorption capabilities remained the same with increasing incubation time to the $21^{\text {st }}$ day. The sample incubated at $25^{\circ} \mathrm{C}$ followed a similar trend, though the reduction was much slower, as after an incubation period of 1 day, gold adsorption ability was reduced by $66 \%$. Sorption decreased further to a final value of $96 \%$ after 21 days.

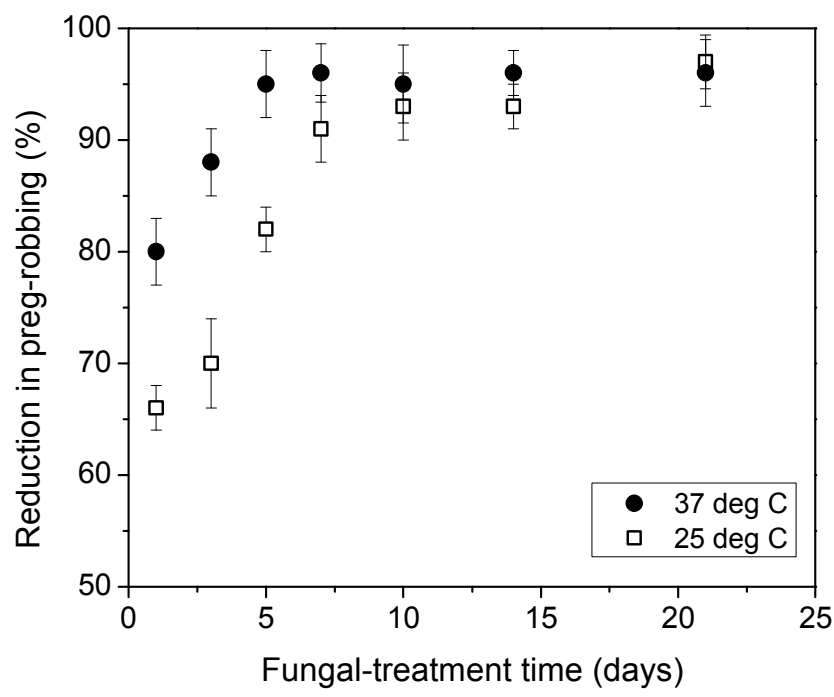

Figure 5. Effect of fungal-treatment time and temperature on preg-robbing by CM. Biotransformation was conducted at $25^{\circ} \mathrm{C}$ and $37^{\circ} \mathrm{C}$ under stationary culturing at $60 \%$ solids and $\mathrm{pH} 6.5$.

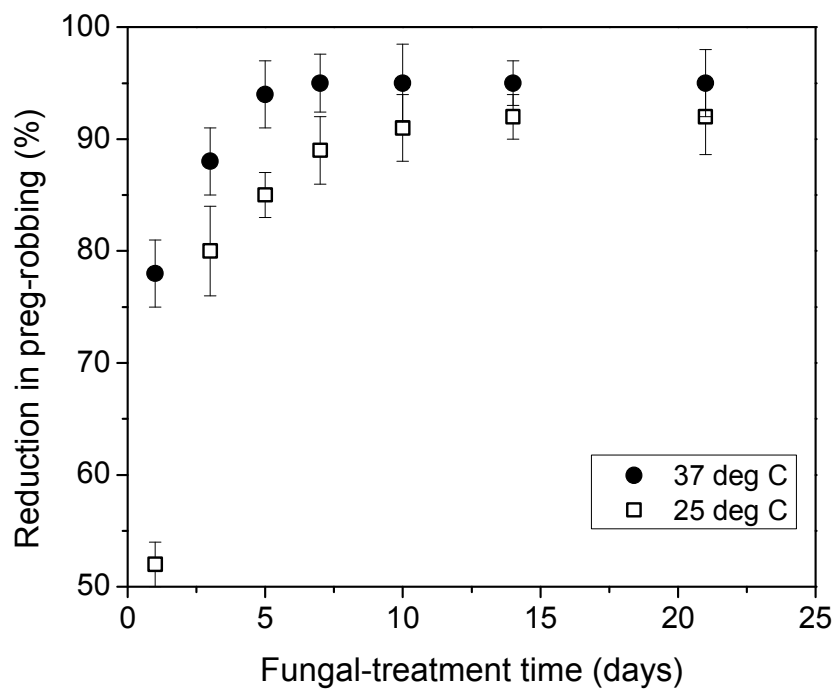

Figure 6. Effect of fungal-treatment time and temperature on preg-robbing by CM. Biotransformation was conducted at $25^{\circ} \mathrm{C}$ and $37^{\circ} \mathrm{C}$ under shake culturing at $25 \%$ solids and $\mathrm{pH} 6.5$.
Figure 6 illustrates the effect of temperature with processing time of up to 21 days, for shake culturing at $25 \%$ solids and $\mathrm{pH} 6.5$. At $37^{\circ} \mathrm{C}$, gold adsorption decreased by $78 \%$ after the $1^{\text {st }}$ day, and followed a plateau at $95 \%$ reduction after the $7^{\text {th }}$ day. The trend is similar to that observed for stationary culturing (Figure 5). For incubation at $25^{\circ} \mathrm{C}$, gold adsorption was halved after the $1^{\text {st }}$ day and decreased by $92 \%$ after 21 days.

It is clear from Figures 5 and 6 that incubation at $37^{\circ} \mathrm{C}$ gives a higher reduction in preg-robbing ability of $\mathrm{CM}$ than at $25^{\circ} \mathrm{C}$ for both stationary and shake culturing. A processing time of 5 to 7 days is also more favorable. Though the temperature for optimum growth of $P$. chrysosporium is $37^{\circ} \mathrm{C}$ [31], the investigation at $25^{\circ} \mathrm{C}$ was essential to assess the changes in preg-robbing behavior at ambient temperature. Work done by Kirk and Farrel [32] shows that $37^{\circ} \mathrm{C}$ provides the microorganism the right temperature for growth and production of oxidative enzymes. This could thus explain the better performance of the fungus at $37^{\circ} \mathrm{C}$ compared with $25^{\circ} \mathrm{C}$. The challenge would therefore be between settling for lower preg-robbing reduction under ambient temperature as against extra heating cost for a higher preg-robbing reduction. Nevertheless, the catalysis of $P$. chrysosporium leads to generation of heat which can sustain reactions above ambient temperature.

\subsection{Effect of pH During Biotransformation on Preg-Robbing by CM}

The effect of $\mathrm{pH}$ on biotransformation of $\mathrm{CM}$ by $P$. chrysosporium was investigated at $\mathrm{pH} 4$ and 6.5. Incubation was conducted at $25 \%$ solids and $37^{\circ} \mathrm{C}$ for 7 days under shake culturing. Figure 7 reveals that after one day of incubation, about $85 \%$ reduction was realized at $\mathrm{pH} 4$ as against $78 \%$ reduction at the near neutral $\mathrm{pH}$. By the $7^{\text {th }}$ day, there was near parity, since at $\mathrm{pH} 4$ and 6.5 , reduction in sorption was $97 \%$ and $95 \%$ respectively.

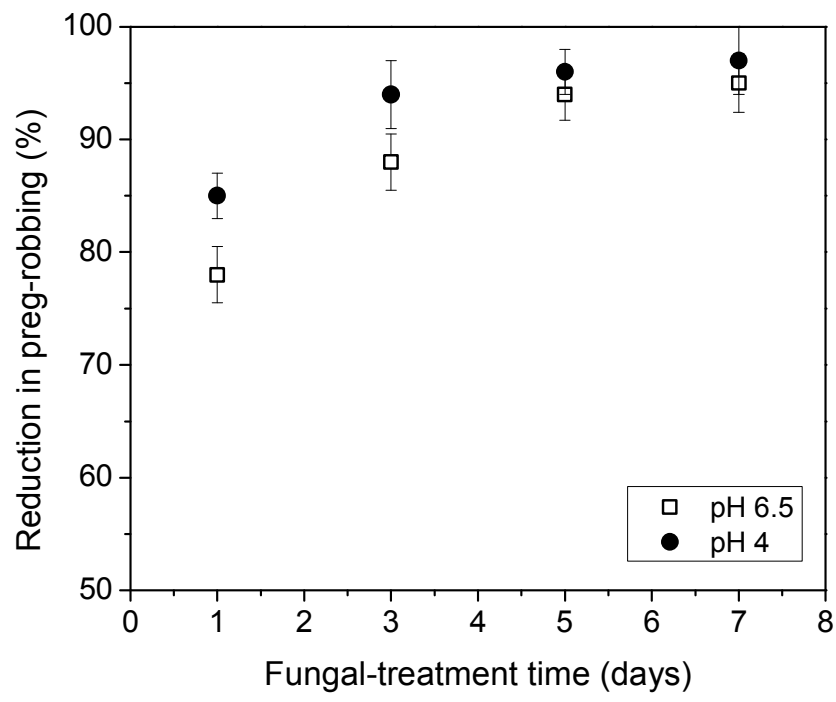

Figure 7. Influence fungal-treatment time and incubation pH on preg-robbing by CM. Biotransformation was conducted at pH 4 and 6.5 under shake culturing at $37^{\circ} \mathrm{C}$ and $25 \%$ solids. 
Investigations by Tien and Kirk (33) indicate that the growth and ability of the fungus to secrete oxidative enzymes peak around $\mathrm{pH} \mathrm{4}$, and this may be responsible for the higher reduction in gold adsorption at that $\mathrm{pH}$ compared to the near-neutral condition. The natural $\mathrm{pH}$ of the fresh culture medium was around 6.5, and for tests where $\mathrm{pH}$ was not controlled, it was observed that $\mathrm{pH}$ decreased over time to between 4 and 5.5. This is because $P$. chrysosporium has the tendency to buffer itself by producing organic acids such as oxalic acid $\left((\mathrm{COOH})_{2}\right)$ malonic acid $\left(\mathrm{CH}_{2}(\mathrm{COOH})_{2}\right)$ and tartaric acid $\left(\mathrm{CH}_{3} \mathrm{CHO}_{2}(\mathrm{COO})_{2}\right)$ that enable it to function close to its optimum $\mathrm{pH}[33,34]$. At both $\mathrm{pH}$ values, an incubation time of 5-7 days was found to be suitable.

\subsection{Effect of Sterilization During Biotransformation on Preg-Robbing by CM}

The effect of sterilizing the medium and substrate before fungal inoculation is shown in Figure 8. When incubation was conducted for 3 days, adsorption onto the non-sterile sample decreased by $90 \%$ as against the sterile system that recorded $92 \%$. Sorption reduction for the 5 th and 7 th days were $97 \%$ for the non-sterile while for a similar period, the sterile averaged $96 \%$. Judging from the average values, the non-sterile appeared to offer a slight advantage over the sterile.

The main aim of sterilization is to get rid of resident microorganisms that are naturally present in the media and/or substrate to be treated. Thus, in the unsterilized culture, there will be other microorganisms aside the one specifically used for inoculation. Consequently, the seemingly slight advantage might be due to positive contribution of native microorganisms, in the medium and/or the substrate, to the biotransformation action of $P$. chrysosporium. It might also be the result of excess production of oxidative enzymes by $P$. chrysosporium in response to competitive and antagonistic survival against other possible native microorganisms [35].

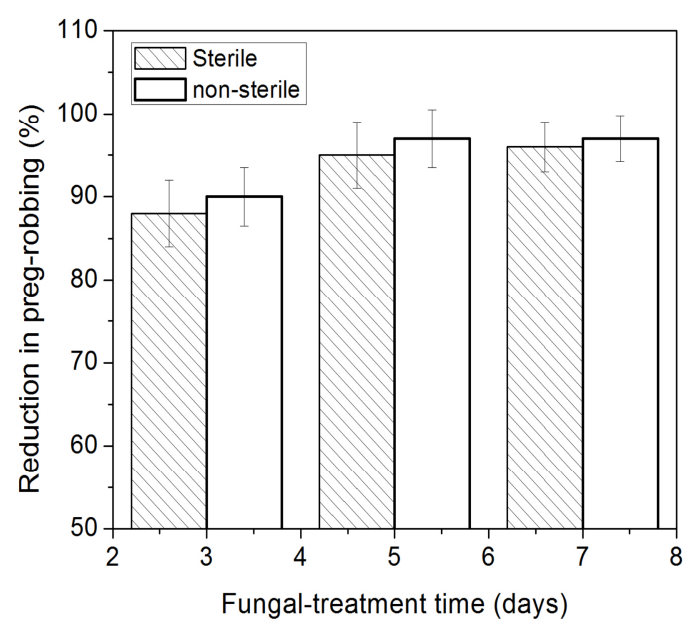

Figure 8. Effect of fungal-treatment time and sterilization on preg-robbing by CM. Biotransformation was conducted at pH 6.5 under stationary culturing at $37^{\circ} \mathrm{C}$ and $60 \%$ solids.

\subsection{Effect of Growth Medium During Biotransformation on Preg-Robbing by CM}

Figure 9 depicts the contribution of the growth medium (MWB) to the biotransformation action of $P$. chrysosporium. The lower portions of the bars represent percentages of the total biotransformation attributed to the medium alone whereas the upper portions show the additional reduction in preg-robbing capacity of $\mathrm{CM}$ when the medium was cultured with $P$. chrysosporium. In the presence of the fungus, there was 4-8 fold decrease in gold adsorption in comparison with the media alone. The slight decline in preg-robbing due to the medium alone may be attributed to fine suspended particulates that might have blinded some of the pores on the carbonaceous material [11].

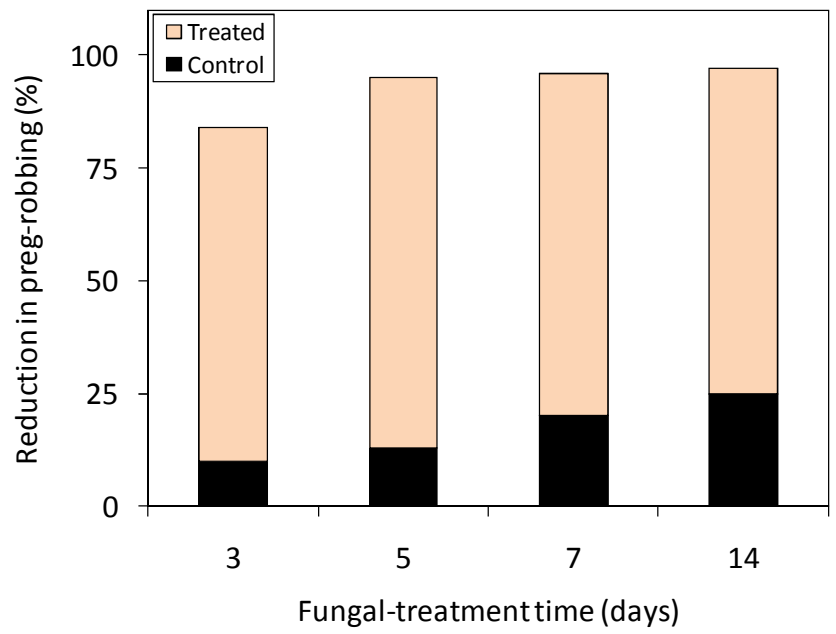

Figure 9. Combined effect of MWB and fungus in the biotransformation of CM. Biotransformation was conducted at pH 6.5 under stationary culturing at $37^{\circ} \mathrm{C}$ and $60 \%$ solids.

\section{Conclusion}

The white rot basidiomycetous fungus, Phanerochaete chrysosporium was utilized in reducing gold adsorption by anthracite coal which served as surrogate for carbonaceous matter in refractory gold ores. Fungal treatment resulted in reduction of the gold adsorption ability of $\mathrm{CM}$ by more than $90 \%$ in a mixture of millet and wheat bran medium MWB).

Fungal modification with $P$. chrysosporium was found to take place in a wide range of time, pulp density, temperature, $\mathrm{pH}$, degree of sterilisation and level of agitation. After contact with the fungus, gold adsorption ability of $\mathrm{CM}$ decreased by about $90-97 \%$, depending on the incubation conditions. A pH of 4 and temperature of $37^{\circ} \mathrm{C}$ were found to enhance biotransformation. Stationary culturing permitted the use of higher pulp densities, and the best pulp densities for stationary and shake culturing respectively were $60 \%$ and $25 \%$ solids. Altogether, strict choices of the parameters will depend on materials required to be treated, techniques available for treatment and post-incubation harvesting. Other considerations are a balance between capacity/tonnage, extra cost on reagents and processing time. Firm decisions can be taken when cost analysis is conducted. 


\section{Competing Interest}

The authors declare that they have no competing interest.

\section{References}

[1] Abotsi, G. M. K., Osseo-Asare, K., (1987), "Surface chemistry of carbonaceous gold ores. II. Effects of organic additives on gold adsorption from cyanide solution”, International Journal of Mineral Processing 21, 225-239.

[2] Adams, M. D. Burger, A. M., (1998), "Characterization and blinding of carbonaceous preg-robbers in gold ores", Minerals Engineering 11, 919-927.

[3] Afenya, P. M., (1991), "Treatment of carbonaceous refractory gold ores", Minerals Engineering 4, 1043-1055.

[4] Amankwah, R. K., Yen, W. T., (2006), Effect of carbonaceous characteristics on biodegradation and preg-robbing behaviour, in: Proceedings of the 23rd International Mineral Processing Congress, Promed Advertising Limited, Instanbul, 1445-1451.

[5] Arriagada, F. J., Osseo-Asare, K., (1984), "Gold extraction from refractory ores: roasting behavior of pyrite and arsenopyrite", in: Precious Metals: Mining, Extraction and Processing, The Metallurgical Society of AIME, Warrendale, PA, 367-385.

[6] Brierley, J. A., Kulpa, C. F., (1993), "Biometallurgical treatment of precious metal ores having refractory carbon content", U. S. Patent, 5,244,493.

[7] Hutchins, S. E., Brierley, J. A., Brierley, C. L., (1988), "Microbial pretreatment of refractory sulfide and carbonaceous ores improves the economics of gold recovery", Mining Engineering 40, 249-254.

[8] Kohr, W. J., (1994), "Method of recovering gold and other precious metals from carbonaceous ores", US Patent, $5,338,338$.

[9] Portier, R. J., (1991), "Biohydrometallurgical processing of ores, and microorganisms therefor, US Patent, 5,021,088.

[10] Rees, K. L., Van Deventer, J. S. J., (2000), “The mechanism of enhanced gold extraction from ores in the presence of activated carbon", Hydrometallurgy 58, 151-167.

[11] Ofori-Sarpong, G., Tien, M., Osseo-Asare, K., (2010), "Myco-hydrometallurgy: Coal model for potential reduction of preg-robbing capacity of carbonaceous gold ores using the fungus, Phanerochaete chrysosporium", Hydrometallurgy 102, 66-72.

[12] Ofori-Sarpong, G., Amankwah, R. K. and Osseo-Asare, K. (2013), "Reduction of Preg-robbing by Biomodified Carbonaceous Matter - A Proposed Mechanism", Minerals Engineering, Vol. 42, pp. 29-35.

[13] Amankwah, R. K., Yen, W. T. Ramsay, J., (2005), "A two-stage bacterial pretreatment process for double refractory gold ores", Minerals Engineering 18, 103-108.

[14] Yen, W. T., Amankwah, R. K., Choi, Y., (2008), Microbial pre-treatment of double refractory gold ores, in: Proceedings of the Sixth International Symposium, Hydrometallurgy 2008, Phoenix, USA. SME, Littleton, CO, 506-510.

[15] Afidenyo, J. K., (2008), Microbial pre-treatment of double refractory gold ores. MSc Thesis, Queen's University, Kingston, Ontario, Canada.

[16] Hausen, D. M., Bucknam, C. H., (1985), Study of preg robbing in the cyanidation of carbonaceous gold ores from Carlin, Nevada, in: Proceedings of the Second International Congress on Applied Mineralogy, AIME, Warrendale, PA, 833-856.

[17] Osseo-Asare, K., Afenya, P. M., Abotsi, G. M. K., (1984), Carbonaceous Matter in Gold Ores; Isolation, Characterization and Adsorption Behavior in Aurocyanide Solution, in: Precious Metals: Mining, Extraction and Processing, The Metallurgical Society of AIME, Warrendale, PA, 125-144.

[18] Pyke, B. L., Johnston, R. F., Brooks, P., (1999), "The characterisation and behaviour of carbonaceous material in a refractory gold bearing ore", Minerals Engineering 12, 851-862.

[19] Schmitz, P. A., Duyvesteyn, S., Johnson, W. P., Enloe, L., McMullen, J., (2001), "Adsorption of aurocyanide complexes onto carbonaceous matter from preg-robbing Goldstrike ore", Hydrometallurgy 61, 121-135.

[20] Sibrell, P. L., Wan, R. Y., Miller, J. D., (1990), Spectroscopic analysis of passivation reactions for carbonaceous matter from Carlin trend ores, in: Proceedings of the Gold '90 Symposium, SME, Inc., Littleton, CO, 355-363.

[21] Stenebraten, J. F., Johnson, W. P., McMullen, J., (2000), "Characterization of Goldstrike Ore Carbonaceous Material Part 2", Minerals and Metallurgical Processing 17, 7-15.

[22] Vaughan, J. P. Kyin, A., (2004), "Refractory gold ores in Archaean greenstones, Western Australia: mineralogy, gold paragenesis, metallurgical characterization and classification", Mineralogical Magazine 68, 255-277.

[23] Ibrado, A. S., Fuerstenau, D. W., (1992), "Effect of the structure of carbon adsorbents on the adsorption of gold cyanide", Hydrometallurgy 30, 243-256.

[24] Ibrado, A. S., Fuerstenau, D. W., (1995). Infrared and X-ray Photoelectron Spectroscopy Studies on the Adsorption of Gold Cyanide on Activated Carbon. Minerals Engineering 8, 441-458.

[25] Jones, W. G., Klauber, C., Linge, H. G., (1989). Fundamental aspects of gold cyanide adsorption on activated carbon, Chapter 32, in: Bhappu, R. B., Handen, R. J. (Eds.), Gold Forum on Technology and Practices - 'World Gold '89', SME, Littleton, Co, 278-281.

[26] Klauber, C., (1991), "X-ray photoelectron spectroscopic study of the adsorption mechanism of aurocyanide onto activated carbon", Langmuir 7, 2153-2159.

[27] Van Vuuren, C. P. J. Snyman, C. P. Boshoff A. J., (2000), ”Gold losses from cyanide solutions part II: The influence of the carbonaceous materials present in the shale material", Minerals Engineering 13, 1177-1181.

[28] Szulczewski, M., Helmke, P., Bleam, W., (2001), "XANES spectroscopy studies of $\mathrm{Cr}(\mathrm{VI})$ reduction by thiols in organosulfur compounds and humic substances", Environ. Sci. Technol. 35, 1134-1141.

[29] Seiter, J. M., Staats-Borda, K. E., Ginder-Vogel, M. and Sparks D. L., (2008), "XANES Spectroscopic Analysis of Phosphorus Speciation in Alum-Amended Poultry Litter", Journal of Environmental Quality 37, 477-485. 
[30] Liu, Q., Yang, H-y., Tong, L-1. (2014), Influence of Phanerochaete chrysosporiumon degradation and preg-robbing capacity of activated carbon. Trans. Nonferrous Met. Soc. China 24, 1905-1911.

[31] McDougall, G. J., Hancock, R. D., (1981), "Gold complexes and activated carbon - a literature review", Gold Bulletin 14, 138-153.

[32] Tien, M., Kirk, T. K., (1988), "Lignin peroxidase of Phanerochaete chrysosporium", Methods in Enzymology 161, 238-249.

[33] Kirk, T. K., Farrell, R. L., (1987), "Enzymatic combustion": The microbial degradation of lignin, Annual Review of Microbiology 41, 465-505.
[34] Tien, M., Kirk, T. K., (1984), Lignin-degrading enzyme from Phanerochaete chrysosporium: purification, characterization and catalytic properties of a unique $\mathrm{H}_{2} \mathrm{O}_{2}$-requiring oxygenase, in: Proceedings of the National Academy of Sciences, U. S. A., 81, 2280.

[35] Fakoussa, R. M., Hofrichter, M., (1999), "Biotechnology and microbiology of coal degradation", Applied Microbiology and Biotechnology 52, 25-40.

[36] Madigan, M. T., Martinko, J. M., (2006). Brock Biology of Microorganisms, $11^{\text {th }}$ ed., Pearson Prentice Hall, Upper Saddle River, NJ. 